\title{
Impact of renal insufficiency on mortality in patients with ST-segment elevation myocardial infarction treated with primary percutaneous coronary intervention
}

\author{
Jonas Emil Sabroe, Per Thayssen, Lisbeth Antonsen, Mikkel Hougaard, Knud Nørregaard Hansen \\ and Lisette Okkels Jensen ${ }^{*}$
}

\begin{abstract}
Background: Chronic kidney disease is associated with increased risk of mortality. We examined the impact of moderate and severe renal insufficiency (RI) on short- and long-term mortality among unselected patients with ST-segment elevation myocardial infarction (STEMI) treated with primary percutaneous coronary intervention (PCI).

Methods: From January 1, 2002 to December 31, 2010 all patients with STEMI treated with primary PCI were identified. The hazard ratio (HR) for death was estimated using a Cox regression model, controlling for potential confounders. RI was defined as creatinine clearance $(\mathrm{CrCl})<60 \mathrm{~mL} / \mathrm{min}$ (moderate $\mathrm{Rl}: \mathrm{CrCl} \leq 30<60 \mathrm{~mL} / \mathrm{min}$ and severe $\mathrm{Rl}: \mathrm{CrCl}<30 \mathrm{~mL} / \mathrm{min}$ ).

Results: The study cohort consisted of 4,116 patients of whom 898 (21.8\%) had RI and 3,218 (78.2\%) had a $\mathrm{CrCl} \geq 60 \mathrm{~mL} / \mathrm{min}$. Compared to patients without Rl, patients with Rl were older, more often female and more likely to have diabetes mellitus, hypertension and to present with a higher Killip class.

Among patients with a preserved kidney function and patients with RI, 30-day all-cause mortality was $3.5 \%$ vs. 20.9\% (log-rank $p<0.001$ ); 1 -year all-cause mortality was 5.7\% vs. 29.4\% (log-rank $p<0.001$ ); 5 -year all-cause mortality was $13.4 \%$ vs. $47.4 \%$ (log-rank $p<0.001$ ). Moderate and severe RI were associated with higher 1-year mortality compared to patients with a preserved renal function $(\mathrm{CrCl} \leq 30<60 \mathrm{~mL} / \mathrm{min}$ : adjusted $\mathrm{HR} 2.71$ [95\% Cl 2.09-3.51], $\mathrm{p}<0.001)$, and $(\mathrm{CrCl}<30 \mathrm{~mL} / \mathrm{min}$ : adjusted HR 7.09 [4.82-10.44], $\mathrm{p}<0.001)$.
\end{abstract}

Conclusion: In unselected STEMI patients treated with primary PCl, moderate and severe RI were associated with increased risk of mortality.

Keywords: ST-segment elevation myocardial infarction, Renal insufficiency, Mortality

\section{Background}

Cardiovascular disease (CVD) is a leading cause of death in the western countries [1]. Studies have shown that impaired renal function is to be considered a risk factor in relation to CVD and patients suffering from renal disease have a higher risk of CVD [2-4]. Also, chronic kidney disease (CKD) is found to be strongly associated with an increased risk of myocardial infarction (MI) and CVD mortality [5,6]. Furthermore, CKD is found to affect patients on a global scale and with an increasing

\footnotetext{
*Correspondence: okkels@dadlnet.dk

Department of Cardiology, Odense University Hospital, Sdr. Boulevard 29, 5000 Odense, Denmark
}

incidence and prevalence [7]. After ST-segment elevation MI (STEMI) and non-STEMI the mortality has been reported to be significantly higher among patients with renal disease compared to patients with preserved renal function [8-10]. Today primary PCI is the recommended reperfusion strategy when treating patients with STEMI, which also applies to STEMI patients with renal dysfunction [11]. Limited data are available on the outcome after primary PCI in STEMI patients with RI, because they have been underrepresented in randomized trials, as renal failure is a commonly used exclusion criterion [12].

\section{Biomed Central}


In our study, data from the Western Denmark Heart Registry (WDHR) were used in order to assess the impact of moderate and severe renal insufficiency (RI) on short- and long-term mortality among unselected STEMI patients treated with primary PCI. Primary PCI has been the recommended treatment for STEMI after publication of the results of the DANish trial in Acute Myocardial Infarction-2 (DANAMI-2) in 2003 [13].

\section{Methods}

\section{Setting and design}

The study was conducted using WDHR for patients treated at Odense University Hospital. A detailed description of the databases has been reported previously [14]. The study was a registry study and ethical approval was not required.

\section{Patients and procedures}

To be eligible for primary PCI, patients must meet the following criteria: 1) symptoms present less than 12 hours from onset of pain to time of catheterization, and 2) STsegment elevation (at least $0.1 \mathrm{mV}$ in two or more standard leads or at least $0.2 \mathrm{mV}$ in two or more contiguous pre-cordial leads) or a new left bundle-branch block (LBBB). Patient with cardiogenic shock were not excluded. We used the WDHR to identify all primary PCIs performed from January 1, 2002 through December 31, 2010. Drug eluting stent (DES), bare metal stent (BMS), glycoprotein IIb/IIIa receptor blocker, and intra-aortic balloon pump was administered at the operator's discretion. All patients received antiplatelet regimen including a bolus of 10,000 IU heparin, lifelong acetylsalicylic acid (75-150 mg once daily), and clopidogrel with a loading dose of $300 \mathrm{mg}$ followed by maintenance with $75 \mathrm{mg}$ daily. The recommended duration of clopidogrel treatment was 3 to 12 months until November 2002 and 12 months thereafter.

Blood samples were taken from the arterial sheath before the first contrast injection and serum creatinine concentration was assessed in the hospital laboratory. Estimation of renal function is commonly based on estimated creatinine clearance $(\mathrm{CrCl})$. Different methods are available. Studies have shown that The Modification of Diet in Renal Disease (MDRD) formula gives a reliable estimated $\mathrm{CrCl}$ [15-17], representing estimated glomerular filtration ratio (eGFR). Therefore the MDRD formula was used in this study: eGFR = estimated $\mathrm{CrCl}=186 \times$ standardized S-Cr ${ }^{-1.154} \times$ age $^{-0.203} \times 0.742$ [if female] [18]. The unit of this equation is expressed as $\mathrm{mL} / \mathrm{min}$ per $1.73 \mathrm{~m}^{2}$ body surface area. An eGFR less than $60 \mathrm{~mL} / \mathrm{min}$ per $1.73 \mathrm{~m}^{2}$ was considered equivalent to RI. Based on eGFR the study population was divided into three groups, a group with eGFR $\geq 60 \mathrm{~mL} / \mathrm{min}$ per $1.73 \mathrm{~m}^{2}$, a group with moderate $\mathrm{RI}: \mathrm{CrCl} \leq 30<60 \mathrm{~mL} / \mathrm{min}$ per $1.73 \mathrm{~m}^{2}$, and a group with severe RI: $\mathrm{CreaCl}<$ $30 \mathrm{~mL} / \mathrm{min}$ per $1.73 \mathrm{~m}^{2}$. This classification of patients into different stages of CKD is identical with those universally endorsed and based on the National Kidney Foundation data [7] where patients with an eGFR $\geq$ $60 \mathrm{~mL} / \mathrm{min}$ per $1.73 \mathrm{~m}^{2}$ is STAGE I/II, patients with $30 \leq \mathrm{eGFR}<60 \mathrm{~mL} / \mathrm{min}$ per $1.73 \mathrm{~m}^{2}$ are in STAGE III, and patients with eGFR $<30 \mathrm{~mL} / \mathrm{min}$ per $1.73 \mathrm{~m}^{2}$ are in STAGE IV/V.

\section{Endpoints}

Primary end-point of the study was all cause-mortality rate. Data on mortality were obtained from the Danish Civil Registration System [19,20], which has kept electronic records on the gender, date of birth, changes in address, date of emigration, and changes in vital status of the entire Danish population since 1968.

\section{Statistics}

Continuous variables were presented as medians with inter quartile range (IQR 25th, 75th) or mean \pm 1 standard deviations (SD). Medians were compared using the Mann-Whitney $U$ test, and means were compared using the unpaired $t$ test. Categorical variables were presented as numbers and percentages. Distributions of categorical variables were compared using the Chi-square test.

We counted end-point events that occurred during the follow-up period and compared rates for the two groups $\left(\mathrm{CrCl} \geq 60 \mathrm{~mL} / \mathrm{min}\right.$ per $1.73 \mathrm{~m}^{2}$ vs. $\mathrm{CrCl}<60 \mathrm{~mL} / \mathrm{min}$ per $1.73 \mathrm{~m}^{2}$ ). Follow-up began on the date of primary PCI procedure and continued until date of death, December 31, 2010 or after 5 years follow-up (to ensure at least 10\% of the study population at risk), whichever came first. Kaplan-Meier curves for all-cause mortality according to kidney function $\left(\mathrm{CrCl} \geq 60 \mathrm{~mL} / \mathrm{min}\right.$ per $1.73 \mathrm{~m}^{2}, \mathrm{CrCl}$ $\leq 30<60 \mathrm{~mL} / \mathrm{min}$ per $1.73 \mathrm{~m}^{2}$ and $\mathrm{CrCl}<30 \mathrm{~mL} / \mathrm{min}$ per $1.73 \mathrm{~m}^{2}$ ) were obtained.

Cox proportional hazards regression analysis was used to estimate the hazard ratio (HR) mortality. Crude and adjusted hazard ratios (HRs) with 95\% confidence intervals (CIs) were computed. Potential confounders associated with time to death in the univariable Cox regression analysis were included in the multivariable Cox regression model. Thus, in the final model, we adjusted for RI, age diabetes mellitus, hypertension, previous myocardial infarction, treatment with glycoprotein IIb/IIIa receptor blocker, Killip class and duration of procedure. All data analyses were carried out using SPSS software version 20 . A two-sided $P$ value $<0.05$ was considered significant.

\section{Results}

A total of 4,676 consecutive patients were treated with primary PCI for STEMI or new onset LBBB MI at Odense University Hospital between January 1, 2002 and 
December 31, 2010. Mortality data was not available for 83 patients, who were foreign citizens. Patients undergoing a later acute MI after the first index procedure $(\mathrm{n}=223)$ were excluded. In 254 patients the creatinine values were not available. Thus, the final study population consisted of 4,116 patients; of these were 898 patients diagnosed with $\mathrm{RI}$, defined as $\mathrm{CrCl}<60 \mathrm{~mL} / \mathrm{min}$ per $1.73 \mathrm{~m}^{2}$, and 3,218 patients had a preserved kidney function (Figure 1).

Baseline characteristics of patients with RI and patients with a preserved kidney function are listed in Table 1. Patients with RI were older and more likely to be female, to have diabetes, hypertension, previous MI, hypercholesterolemia and less likely to be smokers. Among patients with RI, patients with severe $\mathrm{RI}(\mathrm{CrCl}<$ $30 \mathrm{~mL} / \mathrm{min}$ per $1.73 \mathrm{~m}^{2}$ ) more often had diabetes. Characteristics of angiographic findings, lesions and treatment procedures also differed between patients with normal and reduced $\mathrm{CrCl}$, respectively. Patients with RI were more likely to have multi-vessel disease, a higher Killip class, left main culprit lesion, more complex lesions and longer duration of procedure. Patients with RI were less often treated with DES (Table 2).

The median follow-up interval was 3.3 years (25th 75th percentile: $1.4-5.0$ years), with a 1-year mortality of $10.7 \%(\mathrm{n}=441)$ and 5-year mortality of $17.2 \%(\mathrm{n}=707)$. Among patients with a preserved kidney function and patients with RI, 30-day all-cause mortality was 3.5\% $(\mathrm{n}=112)$ and $20.9 \%(\mathrm{n}=188)$, respectively (log-rank $\mathrm{p}<0.001)$; 1 -year all-cause mortality was $5.7 \%(\mathrm{n}=$ $179)$ and $29.4 \%(\mathrm{n}=262)$, respectively ( $\log$-rank $\mathrm{p}<$ $0.001)$; 5 -year all-cause mortality was $13.4 \%(\mathrm{n}=328)$ and $47.4 \%(\mathrm{n}=379)$, respectively (log-rank $\mathrm{p}<0.001)$. Figure 2 shows the 5 -year all-cause survival of the

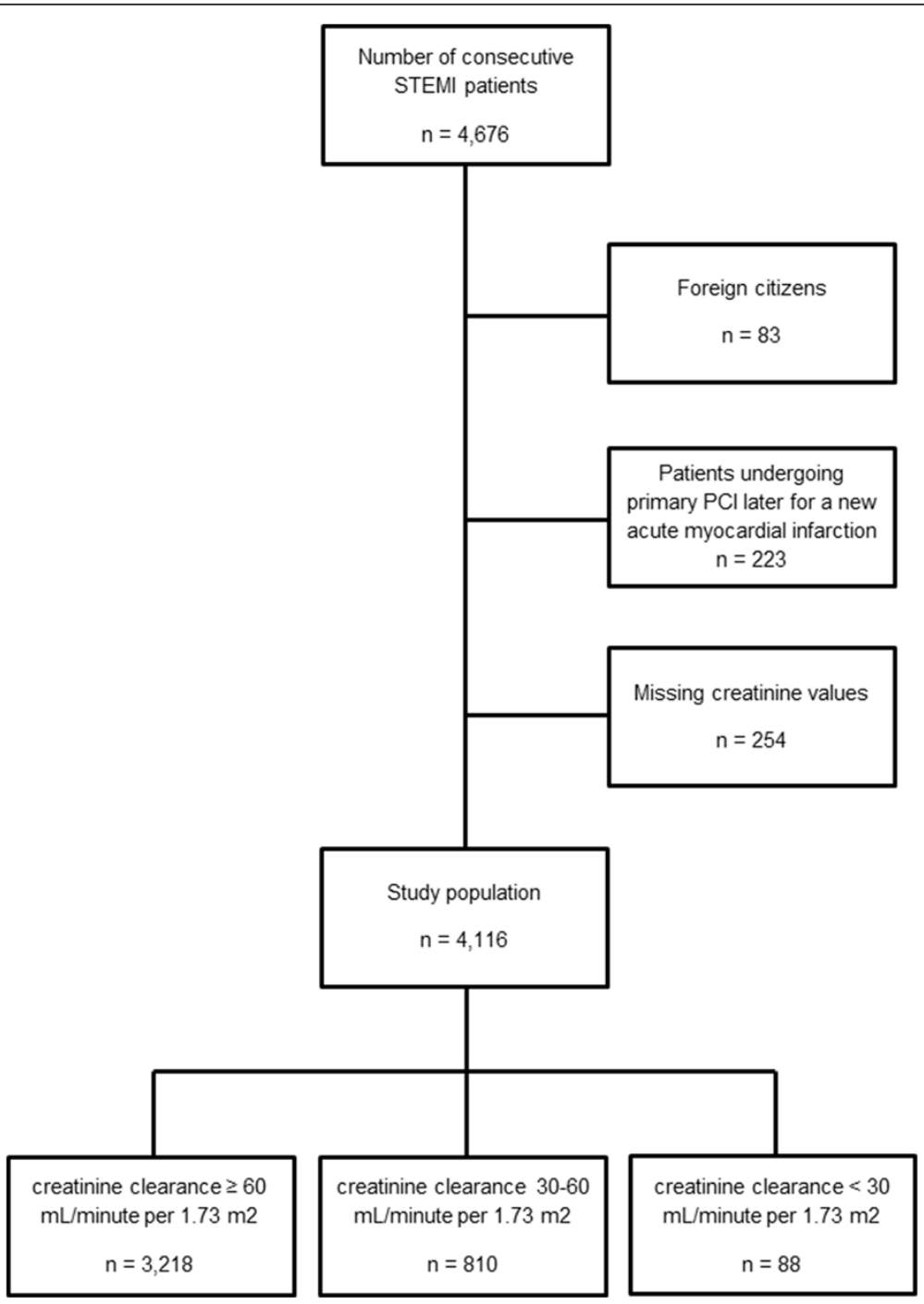

Figure 1 Flow diagram of participant selection. 
Table 1 Baseline clinical characteristics according to kidney function

\begin{tabular}{|c|c|c|c|c|c|c|c|c|}
\hline & $\mathrm{CrCl} \geq 60$ & Valid cases & $\mathrm{CrCl}<60$ & Valid cases & $\begin{array}{l}P \text { value }(\mathrm{CrCl} \geq 60 \\
\text { vs. } \mathrm{CrCl}<60)\end{array}$ & $\mathrm{CrCl} \leq 30<60$ & $\mathrm{CrCl}<30$ & $\begin{array}{l}P \text { value }(\mathrm{CrCl}<30 \text { vs. } \\
\qquad \mathrm{CrCl} \leq 30<60)\end{array}$ \\
\hline Number of patients - no. & 3,218 & 3,218 & 898 & 898 & & 810 & 88 & \\
\hline Male gender - no. (\%) & $2,486(77.3)$ & 3,218 & $524(58.4)$ & 898 & $<0.001$ & $471(58.1)$ & $53(60.2)$ & 0.707 \\
\hline Age - (year) & $61.5 \pm 12.1$ & 3,218 & $73.5 \pm 11.0$ & 898 & $<0.001$ & $73.5 \pm 10.8$ & $72.8 \pm 12.8$ & 0.532 \\
\hline Family history - no. (\%) & 1,235 (39.8) & 3103 & $194(23.5)$ & 824 & $<0.001$ & $178(23.8)$ & $16(20.8)$ & 0.548 \\
\hline Smoking - no. (\%) & $1,712(57.2)$ & 2991 & $290(39.1)$ & 741 & $<0.001$ & $257(38.1)$ & $33(49.3)$ & 0.075 \\
\hline Body Mass Index - $\left(\mathrm{kg} / \mathrm{m}^{2}\right)$ & $26.8(4.4)$ & 2,132 & $26.6(4.6)$ & 507 & 0.256 & $26.7(4.6)$ & $24.9(4.2)$ & 0.009 \\
\hline Diabetes - no. (\%) & $272(8.5)$ & 3218 & $120(13.4)$ & 898 & $<0.001$ & $101(12.5)$ & 19 (21.6) & 0.017 \\
\hline Hypertension - no. (\%) & $930(29.2)$ & 3,180 & $404(46.6)$ & 867 & $<0.001$ & $358(45.8)$ & $46(54.1)$ & 0.143 \\
\hline $\begin{array}{l}\text { Previous coronary artery } \\
\text { bypass grafting - no. (\%) }\end{array}$ & $64(2.0)$ & 3,214 & $23(2.6)$ & 893 & 0.283 & $21(2.6)$ & $2(2.3)$ & 1.000 \\
\hline $\begin{array}{l}\text { Previous percutaneous coronary } \\
\text { intervention - no. (\%) }\end{array}$ & $203(6.4)$ & 3,164 & $58(6.7)$ & 868 & 0.778 & $48(6.1)$ & $10(11.8)$ & 0.048 \\
\hline $\begin{array}{l}\text { Previous myocardial } \\
\text { infarction - no. (\%) }\end{array}$ & $330(10.4)$ & 3,168 & $127(14.5)$ & 875 & 0.001 & $108(13.7)$ & $19(13.7)$ & 0.31 \\
\hline Lipid lowering therapy - no. (\%) & $617(19.4)$ & 3,173 & $201(23.2)$ & 866 & 0.015 & $173(22.2)$ & $28(32.9)$ & 0.025 \\
\hline $\begin{array}{l}\text { Glycoprotein Ilb/llla receptor } \\
\text { blocker - no. (\%) }\end{array}$ & $1,445(48.2)$ & 2,998 & $285(34.4)$ & 828 & $<0.001$ & $263(35.8)$ & $22(26.5)$ & 0.110 \\
\hline Systolic blood pressure - $(\mathrm{mmHg})$ & $122.9 \pm 24.9$ & 2,467 & $118.1 \pm 30.5$ & 662 & $<0.001$ & $118.7 \pm 30.3$ & $112.4 \pm 32.0$ & 0.118 \\
\hline Diastolic blood pressure - $(\mathrm{mmHg})$ & $71.8 \pm 13.9$ & 2,449 & $66.0 \pm 15.1$ & 654 & $<0.001$ & $66.4 \pm 15.1$ & $62.3 \pm 15.9$ & 0.043 \\
\hline
\end{tabular}


Table 2 Angiographic and procedural characteristics according to kidney function

\begin{tabular}{|c|c|c|c|c|c|c|c|c|}
\hline & $\mathrm{CrCl} \geq 60$ & Valid cases & $\mathrm{CrCl}<60$ & Valid cases & $\begin{array}{l}P \text { value }(\mathrm{CreaCl} \geq 60 \\
\text { vs. } \mathrm{CreaCl}<60)\end{array}$ & $\mathrm{CrCl} \leq 30<60$ & $\mathrm{CrCl}<30$ & $\begin{array}{l}P \text { value }(\mathrm{CrCl}<30 \\
\text { vs. } \mathrm{CrCl} \leq 30<60)\end{array}$ \\
\hline Number of patients - no. & 3,218 & 3,218 & 898 & 898 & & 810 & 88 & \\
\hline Multivessel disease no. (\%) & $1,304(41.6)$ & 3,135 & $520(59.4)$ & 876 & $<0.001$ & $464(58.7)$ & $56(65.9)$ & 0.198 \\
\hline Infarct related artery -no. (\%) & & 3,144 & & 867 & $<0.001$ & & & 0.230 \\
\hline Left anterior descending artery - no. (\%) & $1,383(44.0)$ & & $340(39.2)$ & & & $314(40.2)$ & $26(30.6)$ & \\
\hline Left circumflex artery - no. (\%) & $451(14.3)$ & & $109(12.6)$ & & & $100(12.6)$ & $9(10.6)$ & \\
\hline Right coronary artery - no. (\%) & $1,252(39.8)$ & & $374(43.1)$ & & & $329(42.1)$ & $45(52.9)$ & \\
\hline Left main - no. (\%) & $58(1.8)$ & & $44(5.1)$ & & & $39(5.0)$ & $5(5.9)$ & \\
\hline Anterior STEMI or LBBB - no. (\%) & $1,401(45.2)$ & 3,100 & $372(43.1)$ & 864 & $<0.001$ & $343(43.8)$ & $29(35.8)$ & 0.100 \\
\hline Killip class - no. (\%) & & 3,152 & & 878 & $<0.001$ & & & 0.001 \\
\hline । & $2,925(92.8)$ & & $676(77.0)$ & & & $624(78.5)$ & $52(62.7)$ & \\
\hline$\|$ & $135(4.3)$ & & $62(7.1)$ & & & $55(6.9)$ & $7(8.4)$ & \\
\hline III & $51(1.6)$ & & $51(5.8)$ & & & $46(5.8)$ & $5(6.0)$ & \\
\hline IV & $41(1.3)$ & & $89(10.1)$ & & & $70(8.8)$ & $19(22.9)$ & \\
\hline Preintervention TIMI flow - no. (\%) & & 3,143 & & 863 & 0.248 & & & 0.891 \\
\hline Grade 0 & $2,198(54.2)$ & & $2,794(58.7)$ & & & $438(56.2)$ & $49(59.9)$ & \\
\hline Grade 1 & $265(6.5)$ & & $282(5.9)$ & & & $51(6.5)$ & $4(4.8)$ & \\
\hline Grade 2 & $597(14.7)$ & & $623(13.1)$ & & & $117(15.0)$ & $11(13.3)$ & \\
\hline Grade 3 & $978(24.1)$ & & $1,052(22.1)$ & & & $174(22.3)$ & 19 (22.9) & \\
\hline Final TIMI flow - no. (\%) & & 3,143 & & 863 & $<0.001$ & & & 0.097 \\
\hline Grade 0 & $73(2.3)$ & & $50(5.8)$ & & & $41(5.3)$ & $9(10.8)$ & \\
\hline Grade 1 & $28(0.9)$ & & $20(2.3)$ & & & $20(2.6)$ & $0(0.0)$ & \\
\hline Grade 2 & $166(5.3)$ & & $78(9.0)$ & & & $70(9.0)$ & $8(9.6)$ & \\
\hline Grade 3 & $2,876(91.5)$ & & $715(82.9)$ & & & $649(83.2)$ & $66(79.5)$ & \\
\hline Lesion length - mm median (IQR) & $15.00(10.0-20.0)$ & 3,110 & $15.0(10.0-20.0)$ & 855 & 0.676 & $15.00(10.0-20.0)$ & $15.00(10.0-20.0)$ & 0.318 \\
\hline Reference segment - mm median (IQR) & $3.3(3.0-3.6)$ & 3,120 & $3.2(3.0-3.5)$ & 851 & 0.007 & $3.2(3.0-3.5)$ & $3.2(2.8-3.5)$ & 0.320 \\
\hline Minimum lumen diameter - mm median (IQR) & $0.0(0.0-0.2)$ & 3,134 & $0.0(0.0-0.2)$ & 859 & 0.749 & $0.0(0.0-0.2)$ & $0.0(0.0-0.2)$ & 0.625 \\
\hline Sapheneous vein graft - no. (\%) & $10(0.3)$ & 3,145 & $4(0.5)$ & 867 & 0.526 & $2(0.3)$ & $2(2.4)$ & 0.007 \\
\hline Lesion type B2/C & $1,012(32.9)$ & 3,082 & $338(40.3)$ & 838 & $<0.001$ & $302(39.7)$ & $36(46.2)$ & 0.041 \\
\hline Stent length $-\mathrm{mm}$ median (IQR) & $18.0(14.0-23-0)$ & 2,963 & $18.0(14.0-24.0)$ & 754 & 0.913 & $18.0(14.0-24.0)$ & $18.0(13.0-24.0)$ & 0.830 \\
\hline
\end{tabular}


Table 2 Angiographic and procedural characteristics according to kidney function (Continued)

\begin{tabular}{|c|c|c|c|c|c|c|c|c|}
\hline Stent number - no. (\%) & & 3,218 & & 898 & $<0.001$ & & & 0.007 \\
\hline 0 & $255(7.9)$ & & $144(16.0)$ & & & $120(14.8)$ & $24(27.3)$ & \\
\hline 1 & $2,578(80.1)$ & & $643(71.6)$ & & & $591(73.0)$ & $52(59.1)$ & \\
\hline $2+$ & $385(12.0)$ & & $111(12.4)$ & & & $99(12.2)$ & $12(13.6)$ & \\
\hline Drug-eluting stent - no. (\%) & $1,962(62.4)$ & 3,146 & $366(41.4)$ & 885 & $<0.001$ & $338(42.3)$ & $28(32.6)$ & 0.007 \\
\hline Max balloon pressure - atm median (IQR) & $16.0(14.0-18.0)$ & 3,075 & $15.5(14.0-17.3)$ & 814 & 0.086 & $15.5(14.0-17.0)$ & $15.5(14.0-18.0)$ & 0.899 \\
\hline Max balloon diameter - mm median (IQR) & $3.6(3.2-3.8)$ & 3,073 & $3.4(3.2-3.8)$ & 814 & 0.012 & $3.4(3.2-3.8)$ & $3.3(3.0-3.7)$ & 0.126 \\
\hline Duration of procedure - minutes median (IQR) & $16.0(10.0-26.0)$ & 3,205 & $17.0(11.0-28.0)$ & 895 & 0.008 & $17.0(11.0-28.0)$ & $20.0(12.0-30.8)$ & 0.238 \\
\hline Flouro time - minutes median (IQR) & $6.4(4.0-11.2)$ & 3,174 & $7.7(4.5-13.0)$ & 878 & $<0.001$ & $7.5(4.4-13.0)$ & $9.0(6.0-13.3)$ & 0.077 \\
\hline Contrast - ml median (IQR) & $120.0(75.0-180.0)$ & 877 & $100.0(75.0-175.0)$ & 3,159 & 0.007 & $120.0(75.0-185.0)$ & $110.0(80.0-174.0)$ & 0.572 \\
\hline
\end{tabular}

STEMI: ST-segment elevation myocardial infarct.

LBBB: new onset left bundle branch block.

IQR: Interquartile range. 

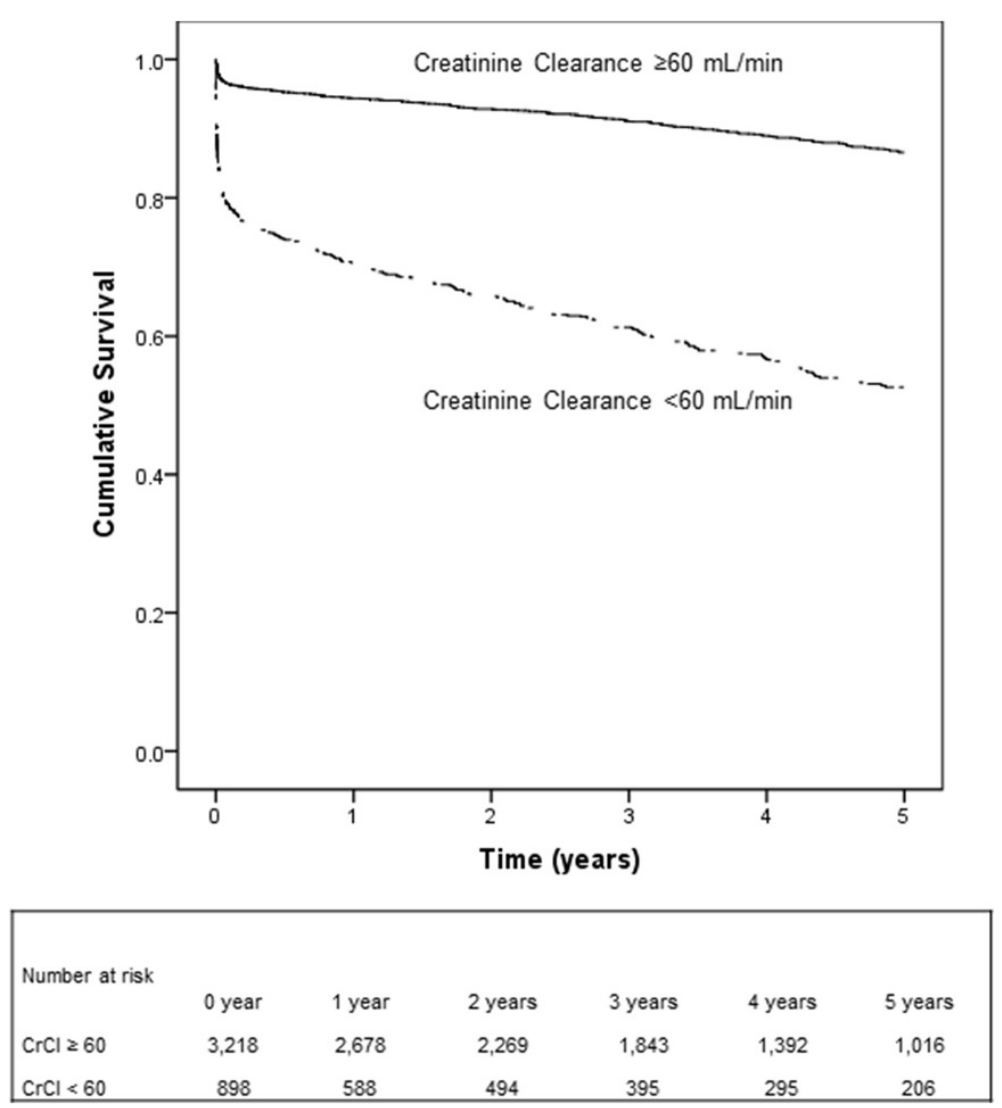

Figure 2 Kaplan-Meier curves for all-cause mortality in patients with $\mathrm{CrCl}<60 \mathrm{~mL} / \mathrm{min}$ per $1.73 \mathrm{~m}^{2}$ and $\mathrm{CrCl} \geq 60 \mathrm{~mL} / \mathrm{min} \mathrm{per} 1.73 \mathrm{~m}$.

study population when stratified into two groups with $\mathrm{CrCl}<60 \mathrm{~mL} / \mathrm{min}$ per $1.73 \mathrm{~m}^{2}$ and $\mathrm{CrCl} \geq 60 \mathrm{~mL} / \mathrm{min}$ per $1.73 \mathrm{~m}^{2}$ respectively.

Among patients with RI (group 1: $\mathrm{CrCl}<30 \mathrm{~mL} / \mathrm{min}$ per $1.73 \mathrm{~m}^{2}$ and group 2: $\mathrm{CrCl} \leq 30<60 \mathrm{~mL} / \mathrm{min}$ per $1.73 \mathrm{~m}^{2}$ ) the all-cause mortality rates were: at 30-day, $40.9 \%(n=36)$ group 1 vs. $18.8 \%(n=152)$ group 2 (log rank $\mathrm{p}<0.001)$; at 1 -year, $57.5 \%(\mathrm{n}=50)$ group 1 vs. $26.4 \%(\mathrm{n}=212)$ group $2(\log \operatorname{rank} \mathrm{p}<0.001)$ and at 5year, $71.3 \%(n=58)$ group 1 and $44.8 \%(n=321)$ group 2 ( $\log$ rank $\mathrm{p}<0.001)$. Figure 3 shows the 5 -year all-cause survival of STEMI patients when stratified into three groups based on $\mathrm{CrCl}$.

Table 3 shows the crude HR associated with 1-year mortality. $\mathrm{CrCl}<60 \mathrm{~mL} / \mathrm{min}$, diabetes, hypertension, previous myocardial infarction and increasing Killip class were associated with an increased mortality. Male gender and treatment with glycoprotein IIb/IIIa receptor blocker were associated with a lower mortality.

After adjustment for potential confounders (Table 3) we found $\mathrm{CrCl}$, diabetes, age, hypertension and Killip class to be associated with increased 1-year mortality. After adjustment for covariates associated with mortality, RI was associated with increased mortality at 30-day (adjusted HR 2.38, 95\% CI 1.34-4.21), 1-year (adjusted HR 2.29, 95\% CI 1.50-3.50) and 5-year mortality (adjusted HR 2.02, 95\% CI 1.50-2.72) compared to patients with preserved kidney function.

\section{Discussion}

Based on an unselected cohort of STEMI patients this study aimed to explore the impact of renal disease on all-cause mortality among 4,116 STEMI patients treated with primary PCI. In this real-world setting we found, that RI was associated with increased short- and longterm mortality. The strength of the present study is that the patients are unselected, all-comer and consecutive. Today guidelines suggest, that patients with STEMI and renal dysfunction is treated in the same way as other STEMI patients with the exception of administration of contrast dye and some medications [11]. However, as primary PCI in STEMI patients is an emergent therapy; neither the kidney function nor the creatinine clearance level will be known in these patients at the time of the primary PCI. In our registry, most of the patients were diagnosed prehospital in the ambulance and referred directly to the catheterization laboratory, where the first blood sample was collected from the arterial sheath 


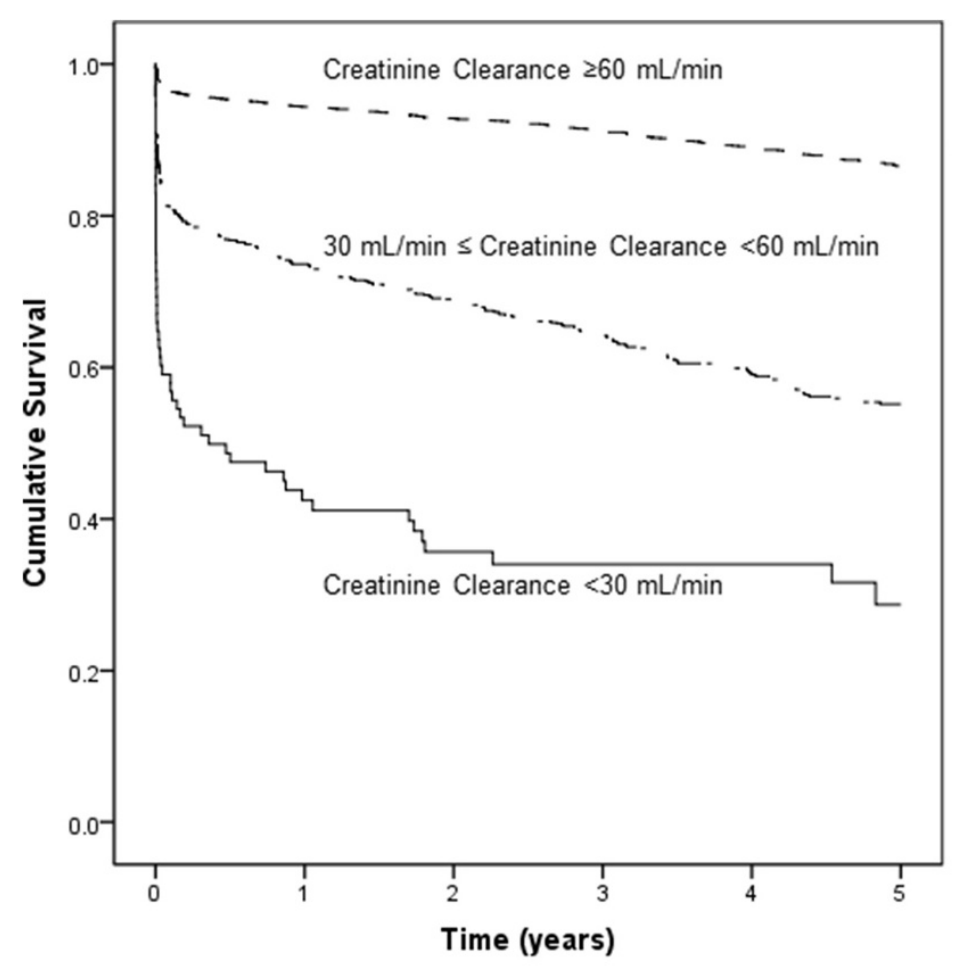

\begin{tabular}{|lrrrrrr|}
\hline Number at risk & & & & & & \\
& Oyears & 1 year & 2 years & 3 years & 4 years & 5 years \\
$\mathrm{CrCl} \geq 60$ & 3,218 & 2,678 & 2,269 & 1,843 & 1,392 & 1,016 \\
$30 \leq \mathrm{CrCl}<60$ & 810 & 556 & 469 & 375 & 281 & 199 \\
$\mathrm{CrCl} 30$ & 88 & 32 & 25 & 20 & 14 & 7 \\
\hline
\end{tabular}

Figure 3 Kaplan-Meier curves for all-cause mortality in patients with $\mathrm{CrCl}<30 \mathrm{~mL} / \mathrm{min}$ per $1.73 \mathrm{~m}^{2} \mathrm{vs}$. $\mathrm{CrCl} \leq 30<60 \mathrm{~mL} / \mathrm{min} \mathrm{per}$ $1.73 \mathrm{~m}^{2}$ and $\mathrm{CrCl} \geq 60 \mathrm{~mL} / \mathrm{min}$ per $1.73 \mathrm{~m}^{2}$.

before contrast injection. In a recent study Fox et al. [12] showed from the Acute Coronary Treatment and Intervention Outcome Network (ACTION) registry, that one third of patients with STEMI had an eGFR $<60 \mathrm{~mL} / \mathrm{min}$ per $1.73 \mathrm{~m}^{2}$. This is a higher number than the $22 \%$ of patients with RI we found in our study, which may be related to the patient population, as patients in the ACTION registry had a different comorbidity risk, as the rate of diabetes mellitus and hypertension were 2 to 3 times higher in the ACTION registry compared to our registry data. In contrast to our study, Fox et al. described that information about kidney function were available to the treating physicians when therapeutic decisions were made, and only $90 \%$ of patients with STEMI received reperfusion therapy $(80 \%$ as primary PCI and $10 \%$ were treated with fibrinolysis). In our study patients with RI were more likely to receive primary PCI without stent implantation and less likely to receive treatment with glycoprotein IIb/IIIa receptor blocker compared to patients without RI. Among 2,597 STEMI and non-STEMI patients Medi et al. [21] found, that patients with RI and comorbidity were less likely to undergo coronary angiography, despite having the same frequency of primary PCI treatment as non-RI patients after angiography.

In our real-world setting registry we found, that RI was associated with increased short- and long-term mortality. This is in accordance with previous studies where RI also has been found to be associated with a higher 30-days mortality and long term mortality [22-25]. Seyfarth et al. [26] found an increase in adjusted hazard ratio after one year follow-up of 1.20 per $10-\mathrm{mL} / \mathrm{min}$ decrease in eGFR. In a study of Morel et al. [27] STEMI and non-STEMI patients were found to have a higher 9month all-cause mortality when diagnosed with renal disease. Sadeghi et al. [28] studied 1,933 patients from the "Controlled Abciximab and Device Investigation to Lower Late Angioplasty Complications (CADILLAC)" trial, where baseline creatinine levels were obtained before angiography, including 350 patients with RI defined as $\mathrm{CrCl}<60 \mathrm{~mL} / \mathrm{min}$ per $1.73 \mathrm{~m}^{2}$. In our registry cohort, both short-term and 1-year mortality rate was more than twice as high as in the study from Sadeghi et al. [28]. This difference is probably caused by (1) an increased 
Table 3 crude and adjusted hazard ratio of covariates associated with 1-year mortality in Cox regression analysis

\begin{tabular}{|c|c|c|c|c|c|}
\hline & Valid cases & $\begin{array}{l}\text { Crude hazard } \\
\text { ratio }(95 \% \mathrm{Cl})\end{array}$ & $P$ value & $\begin{array}{c}\text { Adjusted hazard } \\
\text { ratio }(95 \% \mathrm{Cl})\end{array}$ & $P$ value \\
\hline Male gender & 4,116 & $0.68(0.56-0.83)$ & $<0.001$ & $1.11(0.88-1.41)$ & 0.354 \\
\hline Creatinine clearance & 4,116 & & $<0.001$ & & $<0.001$ \\
\hline Creatinine clearance $\geq 60 \mathrm{~mL} / \mathrm{min}$ & & Reference & & Reference & \\
\hline Creatinine clearance $\leq 30<60 \mathrm{~mL} / \mathrm{min}$ & & $5.31(4.35-6.49)$ & & $2.71(2.09-3.51)$ & \\
\hline Creatinie clearance $<30 \mathrm{~mL} / \mathrm{min}$ & & $15.37(11.27-21.04)$ & & $7.09(4.82-10.44)$ & \\
\hline Age - years & 4,116 & $1.07(1.06-1.08)$ & $<0.001$ & $1.04(1.03-1.06)$ & $<0.001$ \\
\hline Diabetes mellitus & 4,116 & $2.47(1.95-3.13)$ & $<0.001$ & $1.77(1.33-2.35)$ & $<0.001$ \\
\hline Hypertension & 4,047 & $1.26(1.03-1.53)$ & 0.025 & $1.40(1.11-1.76)$ & 0.004 \\
\hline Previous myocardial infarction & 4,043 & $1.99(1.57-2.53)$ & $<0.001$ & $1.53(1.14-2.07)$ & 0.006 \\
\hline Glycoprotein IIb/IIla receptor blocker & 3,826 & $0.49(0.40-0.61)$ & $<0.001$ & $0.68(0.53-0.86)$ & $<0.001$ \\
\hline Multivessel disease & 4,011 & $2.32(1.91-2.83)$ & $<0.001$ & $1.15(0.90-1.46)$ & 0.265 \\
\hline Infarct related artery & 4,011 & & $<0.001$ & & 0.023 \\
\hline Right coronary artery & & Reference & & Reference & \\
\hline Left anterior descending artery & & $1.19(0.96-1.48)$ & & $1.31(1.03-1.68)$ & \\
\hline Left circumflex artery & & $1.02(0.74-1.40)$ & & $1.24(0.88-1.74)$ & \\
\hline Left main & & $4.02(2.73-5.92)$ & & $1.92(1.20-3.08)$ & \\
\hline Killip class & 4,030 & & $<0.001$ & & $<0.001$ \\
\hline I & & Reference & & Reference & \\
\hline$\|$ & & $2.32(1.64-3.30)$ & & $1.20(1.20-2.69)$ & \\
\hline III & & $4.54(3.17-6.51)$ & & $1.68(1.68-3.79)$ & \\
\hline IV & & $9.55(7.32-12.46)$ & & $1.86(2.86-5.75)$ & \\
\hline Duration of procedure - minutes & 4,100 & $1.01(1.01-1.02)$ & $<0.001$ & $1.01(1.00-1.01)$ & 0.007 \\
\hline
\end{tabular}

mortality risk in non-randomized and all-comer patients compared to results from a randomized controlled study and (2) that patients with cardiogenic shock were not excluded in our study. Bertomeu-Gonzales et al. [29] studied the relationship between Killip class and impact of renal disease on mortality and found, that renal disease was stronger associated with mortality in STEMI patients with Killip I compared to patients with a higher Killip class. In our study, patients with RI were more likely to be older and female and they were more likely to have diabetes, hyperlipidemia, and hypertension. The finding of women representing a large proportion of STEMI patients with RI is consistent with findings from other studies [10,28,30,31]. RI was found to be an independent predictor of 1-year mortality whereas we did not find gender to be an independent risk factor for 1year mortality when adjusted for confounders. Similar findings have been made by Damman et al. [32] where 3 -year mortality was found to be associated with a decrease in renal function, whereas gender difference was not proven to be a predictor of mortality after adjustment for confounders.

\section{Limitations}

The validity of our findings depends on data quality and the ability to control for potential confounding. Like all observational studies, our study is prone to biases related to unmeasured factors. Bias due to unknown variables cannot be eliminated. Patients with cardiogenic shock were not excluded from the present study. We did not have systematically access to creatinine values taken in the following days after the primary PCI or information about contrast-induced nephropathy. Patients with RI were more often treated with balloon dilatation without stent implantation or bare metal stent. One explanation for this treatment strategy may be related to the more common finding of severely calcified lesions, which are known to limit complete DES expansion. We also lacked data on causes of mortality, however, in a previous STEMI cohort from Western Denmark Heart Registry, we found that especially the early causes of death was caused by a cardiac reason: the 1-year mortality reason was cardiac in $75 \%$ of the patients, whereas the 3 -year mortality reason is cardiac death in $60 \%$ of the patients [33]. 


\section{Conclusion}

In unselected STEMI patients treated with primary PCI, RI was associated with increased short- and long-term mortality compared to patients with a preserved kidney function.

\section{Competing interests}

The authors declare that they have no competing interests.

\section{Authors' contributions}

JES and LOJ designed the study and were responsible for data management and for design and implementation of the statistical analysis. All other authors enrolled patients or contributed to data collection. JES and LOJ drafted the report, which was subsequently reviewed by all authors. All authors have seen the final submitted report and agree with its contents.

Received: 7 July 2013 Accepted: 28 January 2014

Published: 7 February 2014

\section{References}

1. Mendis S: Cardiovascular risk assessment and management in developing countries. Vasc Health Risk Manag 2005, 1:15-18.

2. Ichikawa K, Konta T, Ikeda A, Fujimoto S, Iseki K, Moriyama T, Yamagata K, Tsuruya K, Yoshida H, Asahi K, Kurahashi I, Ohashi Y, Watanabe T: Significance of past history of renal failure for the detection of high-risk individuals for cardiovascular and end-stage renal disease: analysis of data from a nationwide health checkup. Clin Exp Nephrol 2011, 15:841-847.

3. Furuhashi T, Moroi M, Joki N, Hase H, Masai H, Kunimasa T, Nakazato R, Fukuda H, Sugi K: The impact of chronic kidney disease as a predictor of major cardiac events in patients with no evidence of coronary artery disease. J Cardiol 2010, 55:328-336.

4. Go AS, Chertow GM, Fan D, McCulloch CE, Hsu CY: Chronic kidney disease and the risks of death, cardiovascular events, and hospitalization. N Engl J Med 2004, 351:1296-1305.

5. Meisinger $\mathrm{C}$, Doring $\mathrm{A}$, Lowel $\mathrm{H}$ : Chronic kidney disease and risk of incident myocardial infarction and all-cause and cardiovascular disease mortality in middle-aged men and women from the general population. Eur Heart J 2006, 27:1245-1250

6. Manjunath G, Tighiouart H, Ibrahim H, Macleod B, Salem DN, Griffith JL, Coresh J, Levey AS, Sarnak MJ: Level of kidney function as a risk factor for atherosclerotic cardiovascular outcomes in the community. J Am Coll Cardiol 2003, 41:47-55.

7. Levey AS, Coresh J, Balk E, Kausz AT, Levin A, Steffes MW, Hogg RJ, Perrone RD, Lau J, Eknoyan G, National Kidney F.: National kidney foundation practice guidelines for chronic kidney disease: evaluation, classification, and stratification. Ann Intern Med 2003, 139:137-147.

8. Wright RS, Reeder GS, Herzog CA, Albright RC, Williams BA, Dvorak DL, Miller WL, Murphy JG, Kopecky SL, Jaffe AS: Acute myocardial infarction and renal dysfunction: a high-risk combination. Ann Intern Med 2002, 137:563-570.

9. Menon V, Sarnak MJ, Lessard D, Goldberg RJ: Recent trends in hospital management practices and prognosis after acute myocardial infarction in patients with kidney disease. Am J Cardiol 2004, 94:1290-1293.

10. Seyfarth M, Kastrati A, Mann JF, Ndrepepa G, Byrne RA, Schulz S, Mehilli J, Schomig A: Prognostic value of kidney function in patients with st-elevation and non-st-elevation acute myocardial infarction treated with percutaneous coronary intervention. Am J Kidney Dis 2009, 54:830-839.

11. Steg PG, James SK, Atar D, Badano LP, Blömstrom-Lundqvist C, Borger MA, Di Mario C, Dickstein K, Ducroca G, Fernandez-Aviles F, Gershlick AH, Giannuzzi P, Halvorsen S, Huber K, Juni P, Kastrati A, Knuuti J, Lenzen MJ, Mahaffey KW, Valgimigli M, van 't Hof A, Widimsky P, Zahger D: Task Force on the management of ST-segment elevation acute myocardial infarction of the European Society of Cardiology (ESC). Eur Heart J 2012, 33:2569-2619.

12. Fox CS, Muntner P, Chen AY, Alexander KP, Roe MT, Cannon CP, Saucedo JF, Kontos MC, Wiviott SD: Use of evidence-based therapies in short-term outcomes of st-segment elevation myocardial infarction and non-st-segment elevation myocardial infarction in patients with chronic kidney disease: a report from the national cardiovascular data acute coronary treatment and intervention outcomes network registry. Circulation 2010, 121:357-365.

13. Andersen HR, Nielsen $T$, Rasmussen $K$, Thuesen $L$, Kelbaek $H$, Thayssen $P$, Abildgaard U, Pedersen F, Madsen JK, Grande P, Villadsen AB, Krusell LR, Haghfelt T, Lomholt P, Husted SE, Vigholt E, Kjaergard HK, Mortensen L: A comparison of coronary angioplasty with fibrinolytic therapy in acute myocardial infarction. N Engl J Med 2003, 349:733-742.

14. Jensen LO, Maeng M, Kaltoft A, Thayssen P, Hansen HH, Bottcher M, Lassen JF, Krussel LR, Rasmussen K, Hansen KN, Pedersen L, Johnsen SP, Soerensen HT, Thuesen L: Stent thrombosis, myocardial infarction, and death after drug-eluting and bare-metal stent coronary interventions. J Am Coll Cardiol 2007, 50:463-470

15. Michels WM, Grootendorst DC, Verduijn M, Elliott EG, Dekker FW, Krediet RT: Performance of the cockcroft-gault, mdrd, and new ckd-epi formulas in relation to gfr, age, and body size. Clin J Am Soc Nephrol 2010, 5:1003-1009.

16. Rigalleau V, Lasseur C, Perlemoine C, Barthe N, Raffaitin C, Chauveau P, Combe $\mathrm{C}$, Gin $\mathrm{H}$ : Cockcroft-gault formula is biased by body weight in diabetic patients with renal impairment. Metabolism 2006, 55:108-112.

17. Fesler $P$, Mimran A: Estimation of glomerular filtration rate: what are the pitfalls? Curr Hypertens Rep 2011, 13:116-121.

18. Hallan S, Asberg A, Lindberg M, Johnsen $\mathrm{H}$ : Validation of the modification of diet in renal disease formula for estimating $\mathrm{gfr}$ with special emphasis on calibration of the serum creatinine assay. Am J Kidney Dis 2004, 44:84-93.

19. Pedersen CB, Gotzsche H, Moller JO, Mortensen PB: The danish civil registration system. A cohort of eight million persons. Dan Med Bull 2006, 53:441-449.

20. Epidemiology FL: When an entire country is a cohort. Science 2000, 287:2398-2399.

21. Medi C, Chew DP, Amerena J, Coverdale S, Soman A, Astley C, Rankin J, Brieger D: An invasive management strategy is associated with improved outcomes in high-risk acute coronary syndromes in patients with chronic kidney disease. Intern Med J 2011, 41:743-750.

22. Campbell NG, Varagunam M, Sawhney V, Ahuja KR, Salahuddin N, De PR, Rothman MT, Wragg A, Yaqoob MM, Knight CJ: Mild chronic kidney disease is an independent predictor of long-term mortality after emergency angiography and primary percutaneous intervention in patients with st-elevation myocardial infarction. Heart 2012, 98:42-47.

23. Gibson CM, Pinto DS, Murphy SA, Morrow DA, Hobbach HP, Wiviott SD, Giugliano RP, Cannon CP, Antman EM, Braunwald E: Association of creatinine and creatinine clearance on presentation in acute myocardial infarction with subsequent mortality. J Am Coll Cardiol 2003, 42:1535-1543.

24. Wilson WM, Andrianopoulos N, Clark D, Duffy SJ, Brennan A, Harries I, New G Sebastian M, Loane P, Reid C, Ajani AE: Long-term predictors of mortality after percutaneous coronary intervention in the era of drug-eluting stents. Am J Cardiol 2011, 108:936-942.

25. de Mulder M, van der Ploeg T, de Waard GA, Boersma E, Umans VA: Admission glucose does not improve grace score at 6 months and 5 years after myocardial infarction. Cardiology 2011, 120:227-234.

26. Pinkau T, Mann JF, Ndrepepa G, Mehilli J, Hadamitzky M, Braun S, Kastrati A, Schomig A: Coronary revascularization in patients with renal insufficiency: restenosis rate and cardiovascular outcomes. Am J Kidney Dis 2004, 44:627-635.

27. Morel O, El GS, Jesel L, Radulescu B, Meyer N, Wiesel ML, Caillard S, Campia U, Moulin B, Gachet C, Ohlmann P: Cardiovascular mortality in chronic kidney disease patients undergoing percutaneous coronary intervention is mainly related to impaired p2y12 inhibition by clopidogrel. J Am Coll Cardiol 2011, 57:399-408.

28. Sadeghi HM, Stone GW, Grines CL, Mehran R, Dixon SR, Lansky AJ, Fahy M, Cox DA, Garcia E, Tcheng JE, Griffin JJ, Stuckey TD, Turco M, Carroll JD: Impact of renal insufficiency in patients undergoing primary angioplasty for acute myocardial infarction. Circulation 2003, 108:2769-2775.

29. Bertomeu-Gonzalez V, Nunez J, Nunez E, Facila L, Sanchis J, Bodi V, Pellicer M, Bosch MJ, Martinez A, Chorro FJ, Llacer A: Prognostic effect of renal dysfunction after st-segment elevation myocardial infarction with and without heart failure. Int J Cardiol 2006, 112:159-165.

30. Heer T, Schiele R, Schneider S, Gitt AK, Wienbergen H, Gottwik M, Gieseler U, Voigtlander T, Hauptmann KE, Wagner S, Senges J: Gender differences in acute myocardial infarction in the era of reperfusion (the mitra registry). Am J Cardiol 2002, 89:511-517.

31. Hailer B, Naber C, Koslowski B, Van LP, Schafer H, Budde T, Jacksch R, Sabin G, Erbel R: Gender-related differences in patients with st-elevation myocardial 
infarction: results from the registry study of the st elevation myocardial infarction network essen. Clin Cardiol 2011, 34:294-301.

32. Damman P, Kikkert WJ, Woudstra P, Kuijt WJ, Grundeken MJ, Harskamp RE, Baan J, Vis MM, Henriques JP, Piek JJ, van Straalen JP, Fischer JC, Tijssen JG, de Winter RJ: Gender difference in the prognostic value of estimated glomerular filtration rate at admission in st-segment elevation myocardial infarction: a prospective cohort study. BMJ Open 2012, 2(2):e000322. doi:10.1136/bmjopen-2011-000322.

33. Jensen LO, Maeng M, Thayssen P, Tilsted HH, Terkelsen CJ, Kaltoft A, Lassen JF, Hansen KN, Ravkilde J, Christiansen EH, Madsen M, Sørensen HT, Thuesen L: Influence of diabetes mellitus on clinical outcomes following primary percutaneous coronary intervention in patients with ST-segment elevation myocardial infarction. Am J Cardiol 2012, 109:629-635.

doi:10.1186/1471-2261-14-15

Cite this article as: Sabroe et al:: Impact of renal insufficiency on mortality in patients with ST-segment elevation myocardial infarction treated with primary percutaneous coronary intervention. BMC Cardiovascular Disorders 2014 14:15

\section{Submit your next manuscript to BioMed Central and take full advantage of:}

- Convenient online submission

- Thorough peer review

- No space constraints or color figure charges

- Immediate publication on acceptance

- Inclusion in PubMed, CAS, Scopus and Google Scholar

- Research which is freely available for redistribution 